\title{
Keberadaan Plastik di Lingkungan, Bahaya terhadap Kesehatan Manusia, dan Upaya Mitigasi: Studi Literatur
}

\author{
Yura Witsqa Firmansyah', Mirza Fathan Fuadi ${ }^{2}$, Muhammad Fadli Ramadhansyah ${ }^{3}$, Farida Sugiester $\mathbf{S}^{4}$, \\ Wahyu Widyantoro ${ }^{5}$, Maurend Yayank Lewinsca ${ }^{6}$, Sutra Diyana ${ }^{7}$, Nanda Ika Vera Marliana ${ }^{8}$, Intan Sekar \\ Arumdani $^{9}$, Aziz Yulianto Pratama ${ }^{10}$, Desti Azhari ${ }^{11}$, Ramadani Sukaningtyas ${ }^{12}$, Afdal Hardiyanto ${ }^{13}$ \\ 1,2,3,4,5,6 Program Magister Kesehatan Lingkungan, Fakultas Kesehatan Masyarakat, Universitas Diponegoro \\ ${ }^{7}$ Program Magister Epidemiologi, Sekolah Pascasarjana, Universitas Diponegoro \\ ${ }^{8,9}$ Sarjana Kesehatan Masyarakat, Fakultas Kesehatan Masyarakat, Universitas Diponegoro \\ ${ }^{10}$ Magister Teknik Elektro, Fakultas Teknik, Universitas Diponegoro \\ ${ }^{11}$ Magister Promosi Kesehatan, Fakultas Kesehatan Masyarakat, Universitas Diponegoro \\ ${ }^{121}$ Kantor Kesehatan Pelabuhan Kelas II Tarakan \\ ${ }^{132}$ Kantor Kesehatan Pelabuhan Kelas II Padang \\ *Koresponden email: firmansyahyura@gmail.com
}

Diterima: 11 Agustus 2021

Disetujui: 2 Oktober 2021

\begin{abstract}
Since 2001, synthetic polymers have been one of the most important materials since 2001 because they are used by humans and become a necessity in various sectors such as thermoplastics in countless quantities. Plastics have properties that are difficult to decompose and can change size into plastic macromolecules with the help of photodegradation, oxidation, hydrolytic degradation, and mechanical breakdown . Plastic pollution is a serious problem because the demand for plastic by society is increasing every year and the result of a lot of plastic waste can cause serious health problems and problems in the surrounding environment. Therefore, the use of plastic has a big impact on human health and the environment because it's hard to decompose. The aim of this study is to provide information on the effects of microplastics on the environment through a review study. This study uses a descriptive method with a literature review approach. The criteria for articles used sources from Scopus, Science Direct, ProQuest, SpringerLink, Google Scholar, Nature, JSTOR, and Emerald Insight. The conclusion in this study found a relationship between the presence of microplastics with human health problems, and the environment so that it is necessary to mitigate against plastic waste pollution such as $3 \mathrm{R}$ and substitution of materials.
\end{abstract}

Keywords: plastics waste, human health, mitigation, literature, environment

\begin{abstract}
Abstrak
Polimer sintetik merupakan salah satu materi terpenting sejak tahun 2001 sampai sekarang karena digunakan manusia dan menjadi kebutuhan dalam berbagai sektor seperti termoplastik dengan jumlah yang tidak terkira. Tingginya permintaan termoplastik dapat meningkatkan pencemaran lingkungan. Plastik memiliki sifat yang sukar terurai dan dapat berubah ukuran menjadi makromolekul plastik dengan bantuan foto degradasi, oksidasi, degradasi hidrolitik, dan disintegrasi mekanik. Pencemaran plastik menjadi masalah yang serius karena permintaan plastik oleh masyarakat meningkat setiap tahunnya dan akibat dari banyak sampah plastik dapat menyebabkan masalah kesehatan yang serius dan masalah di lingkungan sekitar. Oleh karena itu, pemakaian plastik memiliki dampak besar terhadap kesehatan manusia, makhluk hidup, dan lingkungan karena dapat sulit untuk terurai. Tujuan penelitian ini adalah memberikan informasi terkait dampak yang ditimbulkan dari keberadaan mikroplastik pada lingkungan berdasarkan kajian review. Penelitian ini menggunakan metode deskriptif dengan pendekatan literature review. Kriteria artikel yang digunakan antara lain bersumber dari Scopus, Science Direct, ProQuest, SpringerLink, Google Scholar, Nature, JSTOR, dan Emerald Insight. Kesimpulan dalam penelitian ini ditemukan hubungan antara keberadaan mikroplastik dengan gangguan kesehatan manusia, makhluk hidup lain, dan lingkungan sehingga perlu dilakukan mitigasi terhadap pencemaran sampah plastik seperti 3R dan substitusi bahan.

Kata kunci: sampah plastik, kesehatan manusia, mitigasi, literatur, lingkungan
\end{abstract}

\section{Pendahuluan}

Polimer sintetik merupakan materi terpenting pada Tahun 2001 hingga sekarang. Polimer sintetik sudah sering digunakan dalam kehidupan manusia dan menjadi kebutuhan dengan jumlah yang tidak bisa diperkirakan [1]. Sifat polimer yang mudah divariasikan menyebabkan polimer sintetik dapat digunakan dalam berbagai sektor. Misalnya polimer sintetik dalam bentuk makromolekul dapat digunakan untuk 
bahan bangunan, hingga penggunaan polimer sintetik menjadi bahan dan alat rumah tangga. Polimer sintetik jenis termoplastik atau plastik lebih banyak digunakan [2] dan dikomersialkan dengan penggabungan zat aditif lainnya stabilisator, isolator api, filler, dan zat warna [3].

Asia memiliki produksi plastik tertinggi, yang menyumbang $49 \%$ dari total produksi dunia, China adalah produsen terbesar dunia (28\%), diikuti oleh Amerika Utara dan Eropa dengan 19\% pada Tahun 2015 [4]. Penghasil polutan plastik terbesar setelah China adalah Indonesia yaitu 0,48-1,29 metrik ton plastik/tahun [5]. Peneliti memprediksi bahwa setiap tahunnya hingga Tahun 2050diperkirakan keberadaan ikan akan tersaingi oleh keberadaan plastik di lautan. Sekitar 500 miliar per tahun menggunakan kantong plastik, sekitar 13 juta ton akhirnya jatuh ke laut, menewaskan sekitar satu miliar orang 100.000 kehidupan laut [4].

Sampah plastik mempunyai watak non-biodegradable, yang maksudnya hendak susah hadapi proses penguraian dalam tanah. Dampaknya, sampah plastik tersebut hendak berganti dimensi jadi makromolekul plastik $(5 \mathrm{~mm})$, dengan dorongan proses fotodegradasi, oksidasi, degradasi hidrolitik serta disintegrasi mekanik hendak membuat dimensi makroplastik jadi mikroplastik dengan dimensi yang lebih kecil [6].

Penciptaan plastik di dunia hadapi kenaikan tiap tahunnya serta menggapai 322 juta ton pada Tahun 2015 [7]. Diperkirakan kalau jumlah penciptaan ini hendak bertambah 100 kali lipat pada Tahun 2050 mendatang [8], [9]. Plastik sendiri nyatanya menyumbang $10 \%$ dari total sampah yang dihasilkan oleh manusia. Sebagian besar plastik yang dibuang tidak hadapi daur ulang serta dibuang ke area serta berakhir di laut. Diperkirakan sebesar 60- 80\% dari sampah yang terdapat di laut berasal dari sampah plastik[10].

Pencemaran plastik di area dikala ini sudah jadi kasus yang sungguh- sungguh. Plastik walaupun bertabiat persisten, bersamaan dengan waktu bisa terdegradasi jadi partikel yang lebih kecil. Hasil riset Jambeck tahun 2015, mengatakan kalau Indonesia ialah kontributor polutan plastik terbanyak di dunia sehabis Cina, dengan besaran 0, 48-1, 29 juta metrik ton plastik/ tahun. Jumlah ini bertambah dari tahun ke tahun bersamaan meningkatnya permintaan plastik oleh warga. Banyaknya sampah plastik di lautan Indonesia hendak berakibat kurang baik terhadap kesehatan serta area dekat [5].

Pemakaian plastik dalam kehidupan tiap hari hadapi kenaikan sebab watak keunggulannya tersebut. Bagi Kemenperin tahun 2013, dekat 1, 9 juta ton plastik dibuat sepanjang tahun 2013 di Indonesia dengan rata- rata penciptaan 1, 65 juta ton/ tahun. Jumlah mengkonsumsi plastik mempengaruhi signifikan terhadap sampah plastik yang dihasilkan. Kota Jakarta misalnya, dengan penduduk sebanyak 9 juta jiwa, serta jumlah sampah per hari dekat 5000 ton hingga jumlah plastik yang ditimbun menggapai 400 ton. Dari tipe tersebut sampah plastik yang ditemui biasanya berjenis PP. Bagi Thompson tahun 2013 memperkirakan kalau 10\% dari seluruh plastik yang baru dibuat hendak dibuang lewat sungai serta berakhir di laut. Perihal ini berarti dekat 165 ribu ton plastik/ tahun hendak bermuara di perairan laut Indonesia.

Hasil riset lain oleh Rohman tahun 2015 di Indonesia menciptakan nanoplastik pada ikan kembung, ikan layang, ikan herring, ikan dari tipe carangidae serta pula ikan baronang. Nanoplastik dalam jumlah

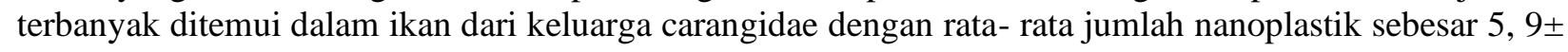
5, 1 partikel per ikan. Nanoplastik yang ditemui dalam saluran pencernaan ikan ini mempunyai wujud fragmen, film, styrofoam, serta monofilament [8].

Nanoplastik bisa menutup saluran pencernaan serta menimbulkan keterbatasan nutrisi. Partikel nanoplastik dipindahkan ke sistem pencernaan lewat bilik usus. Bila nanoplastik masuk ke saluran pencernaan manusia, diprediksi bisa merobek usus ataupun lambung sebab pecahan nanoplastik tidak bisa di cerna di dalam saluran pencernaan, serta sebagian keluar bersama kotoran hendak senantiasa masih terdapat yang tertinggal di dalam badan. Bila masuk ke dalam sel darah, plastik nano ini turut terserap dalam jaringan sel darah serta bisa mengusik sistem syaraf pusat. Apabila sangat kerap bisa menimbulkan kendala sistem pencernaan ataupun sistem syaraf, serta lama- lama bisa menyebabkan kematian.

Selain itu, di dalam garam, air minum, dan kotoran manusia juga ditemukan nanoplastik[11]. Dampak lain yang ditimbulkan oleh nanoplastik terhadap makhluk hidup yaitu hewan adalah dapat menghambat sistem pencernaan dan dapat mempengaruhi kebiasaan makan mereka hingga menyebabkan kematian. Dampak dari nanoplastik terhadap manusia, selain dapat menyebabkan gangguan saluran pencernaan hingga kematian diduga dapat menyebabkan peradangan paru-paru dan keracunan genetik [11].

Konsumsi plastik dalam jumlah yang sangat besar pastinya hendak berakibat signifikan terhadap kesehatan manusia, makhluk hidup serta area sebab plastik memiliki watak susah terdegradasi (nonbiodegradable), plastik diperkirakan membutuhkan 100 hingga 500 tahun sampai bisa terdekomposisi (terurai) dengan sempurna. Dengan demikian konsumsi plastik baik plastik yang masih baru ataupun sampah plastik haruslah bagi persyaratan yang berlaku supaya tidak beresiko terhadap kesehatan serta area. Tujuan penulisan artikel ini untuk mengkaji sejumlah literatur sebagai rujukan keberadaan, bahaya, serta mitigasi terhadap sampah plastik. 


\section{Metode Penelitian}

Penelitian ini menggunakan metode literature review untuk memberikan gambaran keberadaan nanoplastik di lingkungan serta potensi dampak kesehatan manusia. Artikel yang dijadikan studi literatur bersumber dari database jurnal ilmiah yaitu Scopus, Science Direct, ProQuest, SpringerLink, Google Scholar, Nature, JSTOR dan Emerald Insight. Proses skrinning artikel tersaji pada Gambar 1.

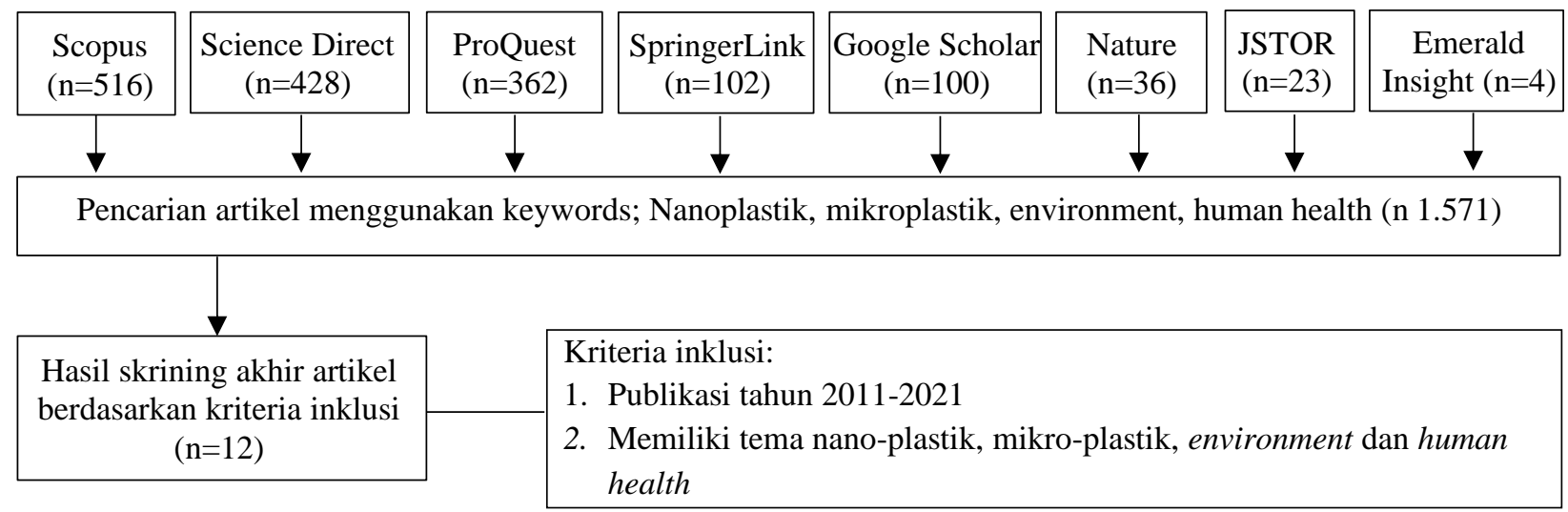

Gambar 1. Bagan skrining artikel

\section{Hasil dan Pembahasan}

\section{Keberadaan Plastik di Lingkungan}

Keberadaan plastik di lingkungan selalu mengalami peningkatan dalam 10 tahun terakhir, disebabkan plastik yang beredar $50 \%$ adalah jenis plastik sekali pakai[12]. Plastik kemasan yang dibuang dari total sampah baik ditemukan di darat atau di laut secara komposisi tidak akan berubah, namun dapat terurai dengan bantuan panas mikrobia menjadi fragmen-fragmen kecil yang kemudian dapat terurai menjadi karbon dioksida dan air [13]. Makroplastik merupakan sumber utama sampah plastik, makroplastik yang terbuang di lingkungan, dapat berubah ukuran, dan termakan oleh konsumen tingkat satu pada rantai makanan, yang kemudian mengalami proses biomagnifikasi pada puncak konsumen tertinggi pada rantai makanan [14].

Keberadaan plastik ditemukan juga dalam industri tekstil, terutama dalam bentuk serat tekstil. Plastik yang dihasilkan dalam ukuran mikrometer dari proses pencucian pakaian yang air limbahnya tidak terfilter dalam instalasi pengolahan air limbah (IPAL) [15]. Sumber limbah domestik juga memungkinkan terhadap mikroplastik, produk perawatan personal dengan bahan dasar polyethylene[16]. Kondisi tersebut membuat sungai-sungai di Indonesia menjadi tercemar dengan tidak adanya IPAL domestik dalam menyaring mikroplastik sehingga langsung dibuang pada badan air [17]. Kajian penelitian terhadap bahan plastik jenis polystyren pada tutup tempat kopi dilakukan di laboratorium dengan memberikan paparan sinar UV yang kemudian dapat terurai menjadi nanoplastik partikel [18].

Keberadaan plastik dalam makanan juga ditemukan, terutama jenis seafood seperti ikan, udang, bivalvia, kerang [19]. Namun pada makanan lain, mikroplastik telah ditemukan seperti pada madu, bir, garam dan gula. Kajian penelitian baru yang dilakukan menggunakan spektrofotometri ditemukan mikroplastik pada air kran, air kemasan, dan air minum dari sumber air tanah [20]. Plastik juga dapat ditemukan dalam penggunaan pestisida pada sektor pertanian. Plastik yang sudah berbentuk pelet resin dalam ukuran mikro dianalisis menggunakan ekstraktor cairan bertekanan untuk memisahkan mikroplastik dari DDT dan OCP [21].

\section{Bahaya Plastik terhadap Kesehatan Manusia}

Adapun bahaya sampah plastik pada kesehatan manusia dapat dilihat pada Tabel 1. Peneliti menggunakan 12 artikel yang terskrinning dengan kriteria inklusif artikel. Keberadaan sampah plastik ditemukan pada tubuh manusia dengan ukuran nano yang dapat memicu terjadinya kanker. Tabel 1 ini merupakan temuan plastik pada sel manusia, yang membahayakan kesehatan manusia terutamanya memicu penyakit kanker. 
Tabel 1. Hasil sintesis artikel tentang bahaya plastik terhadap kesehatan

\begin{tabular}{|c|c|c|}
\hline $\begin{array}{l}\text { Peneliti, } \\
\text { Tahun }\end{array}$ & Temuan & Biomarker \\
\hline $\begin{array}{l}\text { Forte } \\
(2016)[22]\end{array}$ & $\begin{array}{l}\text { Jenis plastik polystyrene ditemukan dalam } \\
\text { ukuran } 44 \mathrm{~nm} \text { dan } 100 \mathrm{~nm} \text { unmodified. }\end{array}$ & $\begin{array}{l}\text { Human gastric } \\
\text { adenocarcinoma cells (AGS) }\end{array}$ \\
\hline $\begin{array}{l}\text { Walczak } \\
(2015)[23]\end{array}$ & $\begin{array}{l}\text { a. Jenis plastik polystyrene, unmodified, } \\
\text { amino-functionalized, carboxylated } \\
\text { b. Ukuran ditemukan } 50 \mathrm{~nm} \text { dan } 100 \mathrm{~nm} \text {, } \\
\text { ukuran bervariasi sesuai biomarker }\end{array}$ & $\begin{array}{l}\text { a. Human colon carcinoma } \\
\text { cells (Caco-2) } \\
\text { b. Human colon } \\
\text { adenocarcinoma cells } \\
\text { (HT29-MTX) } \\
\text { c. Human intestine microfold } \\
\text { cells }\end{array}$ \\
\hline $\begin{array}{l}\text { Fiorentin } \\
(2015)[24]\end{array}$ & $\begin{array}{l}\text { a. Jenis plastik plystyrene dan carboxylated } \\
\text { ditemukan dalam ukuran } 44 \mathrm{~nm} \\
\text { b. Absorpsi partikel maksimum setelah } \\
\text { waktu } 30 \text { menit }\end{array}$ & $\begin{array}{l}\text { Human colon fibroblasts cells } \\
\text { (HCF) }\end{array}$ \\
\hline $\begin{array}{l}\text { Mahler } \\
(2012)[25]\end{array}$ & $\begin{array}{l}\text { a. Jenis plastik polystyrene, amino- } \\
\text { functionalized, dan carboxylated } \\
\text { b. Dapat mempengaruhi absorpsi dan } \\
\text { perjalanan besi } \\
\text { c. Partikel ditemukan dalam ukuran } 50 \mathrm{~nm} \\
\text { dan } 200 \mathrm{~nm}\end{array}$ & $\begin{array}{l}\text { a. Human colon carcinoma } \\
\text { cells (Caco-2) } \\
\text { b. Human colon } \\
\text { adenocarcinoma cells } \\
\text { (HT29-MTX) }\end{array}$ \\
\hline $\begin{array}{l}\text { Inkielewicz- } \\
\text { Stepniak } \\
(2018)[26]\end{array}$ & $\begin{array}{l}\text { a. Jenis plastik polystyren dan amino- } \\
\text { functionalized ditemukan dalam ukuran } \\
57 \mathrm{~nm} \\
\text { b. Mengukur kemampuan sel untuk hidup } \\
\text { dan kematian sel }\end{array}$ & $\begin{array}{l}\text { Human colon carcinoma cells } \\
\text { (Caco-2, , LS174T, HAT-29) }\end{array}$ \\
\hline $\begin{array}{l}\text { Varela } \\
(2012)[27]\end{array}$ & $\begin{array}{l}\text { a. Jenis plastik polystyren dan carboxylated } \\
\text { ditemukan dalam ukuran } 20 \mathrm{~nm}, 40 \mathrm{~nm} \text {, } \\
\text { dan } 100 \mathrm{~nm} \text {. } \\
\text { b. Partikel ukuran } 40 \mathrm{~nm} \text { memiliki proses } \\
\text { lebih cepat daripada ukuran } 20 \text { atau } 100 \\
\text { nm pada absorpsi kedua sel }\end{array}$ & $\begin{array}{l}\text { a. Human lung carcinoma } \\
\text { cells (A549) } \\
\text { b. Human astrocytoma } \\
1321 \mathrm{~N} 1\end{array}$ \\
\hline $\begin{array}{l}\text { Deville } \\
(2015)[28]\end{array}$ & $\begin{array}{l}\text { Jenis plastik polystyren dan carboxylated } \\
\text { ditemukan dalam ukuran } 116 \mathrm{~nm} \text { dan } \\
\text { mengalami absorpsi pada sel }\end{array}$ & $\begin{array}{l}\text { Human lung carcinome cells } \\
\text { (A549) }\end{array}$ \\
\hline $\begin{array}{l}\text { Salvati } \\
(2011)[29]\end{array}$ & $\begin{array}{l}\text { a. Jenis plastik polystyren dan carboxylated } \\
\text { ditemukan dalam ukuran } 40-50 \mathrm{~nm} \\
\text { b. Absorpsi pada sel secara irreversible dan } \\
\text { mengalami peningkatan konsentrasi pada } \\
\text { intracellular }\end{array}$ & $\begin{array}{l}\text { Human lung carcinome cells } \\
\text { (A549) }\end{array}$ \\
\hline $\begin{array}{l}\text { McCarthy } \\
(2011)[30]\end{array}$ & $\begin{array}{l}\text { Jenis plastik polystyren dan carboxylated } \\
\text { ditemukan dalam ukuran } 20 \mathrm{~nm} \text { dan } \\
\text { mengalami aktivasi pada ion transport }\end{array}$ & $\begin{array}{l}\text { Human lung adenocarcinoma } \\
\text { (A549) }\end{array}$ \\
\hline $\begin{array}{l}\text { Chiu } \\
(2015)[31]\end{array}$ & $\begin{array}{l}\text { a. Jenis plastik polystyrene, unmodified, } \\
\text { amino-functionalized, dan carboxylated, } \\
\text { ditemukan dalam ukuran } 60 \mathrm{~nm} \text {. } \\
\text { b. Partikel polystyrene dan amino- } \\
\text { functionalized menyebabkan kematian } \\
\text { pada sell secara autofagositosis dan } \\
\text { melalui induksi yang menyebabkan } \\
\text { endoplasmic reticulum stres }\end{array}$ & $\begin{array}{ll}\text { a. } & \text { Human bronchial } \\
\text { epithelium (BEAS-2B) } \\
\text { b. } \text { Mouse monocyte } \\
\text { macrophage (RAW 264,7) }\end{array}$ \\
\hline $\begin{array}{l}\text { Ruenraroengs } \\
\text { ak dan } \\
\text { Tetley. } \\
(2015)[32]\end{array}$ & $\begin{array}{l}\text { a. Jenis plastik polystyrene, unmodified, } \\
\text { amino-functionalized, dan } \\
\text { carboxylated, ditemukan dalam ukuran } \\
50 \mathrm{~nm} \text { dan } 100 \mathrm{~nm} \text {. } \\
\text { b. Partikel amino-functionalized } \\
\text { menyebabkan stres oksidatif, gangguan } \\
\text { pada mitokondria, cytochrome C keluar } \\
\text { dan kematian cell }\end{array}$ & $\begin{array}{l}\text { b. Human immortalized } \\
\text { alveolar epithelial type } 1 \\
\text { cells (TT1) } \\
\text { c. Primary human alveolar } \\
\text { macrophage (MAC) } \\
\text { d. Primary huma alveolar } \\
\text { type } 2 \text { (AT2) epithelial } \\
\text { cells }\end{array}$ \\
\hline
\end{tabular}


Paget

(2015)[33] a. Jenis plastik polystyrene, unmodified, amino-functionalized, ditemukan dalam ukuran $50 \mathrm{~nm}$

b. Bersifat sitotoksik dan genotoksik pada THP-1
a. Human Calu-3 epithelial
cells
b. Human monocytic
leukemia cell line THP-1

\section{Upaya Mitigasi terhadap Pencemaran Sampah Plastik}

Upaya mitigasi terhadap pencemaran plastik dapat dimulai dengan penerapan prinsip 3R. Prinsip 3R yaitu dengan mengurangi penggunaan tas atau kantong plastik dalam kegiatan perbelanjaan. Penggunaan tas atau kantong plastik secara berulang juga meminimalisir meningkatnya timbulan sampah. Kemudian sampah plastik dapat didaur ulang menjadi banyak kerajinan seperti bunga, tas atau kursi berbahan sampah. Dalam penerapan prinsip 3R dituntut kedisiplinan dan kesadaran masyarakat yang dilibatkan atau berbasis pemberdayaan masyarakat. Peranan pemerintah juga diperlukan dalam mendukung prinsip 3R, seperti di seluruh pusat perbelanjaan dilarang untuk menggunakan tas atau kantong plastik sekali pakai, sehingga masyarakat akan beralih untuk menggunakan tas atau kantong belanjaan yang ramah lingkungan.

Selanjutnya upaya mitigasi dalam pengurangan sampah plastik dapat dilakukan dengan substitusi bahan. Bahan untuk pembuatan plastik ramah lingkungan dapat menjadi salah satu upaya dalam mitigasi pencemaran sampah plastik. Seperti penggunaan limbah sisik ikan sebagai bahan plastik, penggunaan singkong yang diolah menjadi bahan untuk pembuatan plastik.

\section{Kesimpulan}

Keberadaan plastik ditemukan di lingkungan seperti pada makanan, instalasi air limbah, air bersih dan air minum dalam ukuran mikro serta nano. Keberadaan dan bahaya plastik pada kesehatan manusia ditemukan pada sel sebagai unit terkecil yang ada di dalam tubuh manusia sehingga dapat memicu terjadinya kanker. Upaya yang dapat dilakukan dalam pengurangan dan pengendalian jumlah plastik di lingkungan dengan menerapkan 3R serta substitusi bahan baku plastik yang ramah lingkungan.

\section{Ucapan Terima Kasih}

Terima kasih kepada rekan-rekan yang membantu dalam proses pengerjaan artikel. Semoga artikel ini dapat bermanfaat untuk pembaca baik untuk menambah informasi atau dijadikan referensi bacaan.

\section{Singkatan}

$\begin{array}{ll}\text { IPAL } & \text { Instalasi Pengolahan Air Limbah } \\ \text { UV } & \text { Ultraviolet } \\ \text { \% } & \text { Percentage } \\ \text { 3R } & \text { Reduce, Reuse and Recycle }\end{array}$

\section{Referensi}

[1] T. P. Lodge, "Celebrating 50 Years of Macromolecules," Macromolecules, vol. 50, no. 24, p. 9525-9527, 2017.

[2] J. R. Fried, "Polymer Science and Technology," 3rd ed., Pearson Education, Ed. 2014, pp. 1-76.

[3] J. N. Hahladakis, C. A. Velis, R. Weber, E. Iacovidou, and P. Purnell, "An overview of chemical additives present in plastics: Migration, release, fate andenvironmental impact during their use, disposal and recycling," J. Hazard. Mater., vol. 344, p. 179-199, 2018.

[4] A. O. Alabi, A. O. Kehinde, A. Oluwaseun, and E. A. E. Olufiropo, "Public and Environmental Healt Effect of Plastic Wastes Disposal," A Rev., vol. 5, no. 1, 2015.

[5] J. R. Jambeck, R. Geyer, C. Wilcox, T. R. Siegler, M. Perryman, A. Andrady, and K. L. Law, "Plastic waste inputs from land into the ocean," Science (80-. )., vol. 347, no. 6223, pp. 768-771, 2015.

[6] E. Yousif and R. Haddad, "Photodegradation and photostabilization of polymers, especially polystyrene," Rev. SpringerPlus, vol. 2, no. 1, p. 398, 2013.

[7] Plastics Europe, "Plastic - the Facts 2016," 2016. .

[8] C. M. Rochman, S. L. Tahir, D. V Williams, R. Baxa, J. T. Miller, S. Foo-Ching, and S. J. Werorilangi, "Anthropogenic debris in seafood: Plastic debris and fibers from textiles in fish and bivalves sold for human consumption," Nature, 2015.

[9] M. F. M. Santana, L. G. Ascer, M. R. Custódio, F. T. Moreira, and A. Turra, "Microplastic contamination in natural mussel beds from a Brazilian urbanized coastal region: Rapid evaluation 
through bioassessment," Mar. Pollut. Bull., vol. 106, no. 1-2, pp. 183-189, 2016.

[10] C. Karen, Duls Anja, "Microplastic in the aquatic and terrestrial environment: sources (witd a specific focus on personal care products), fate and effects," vol. 28, no. 2, 2016.

[11] V. A. Wirnkor, C. E. Enyoh, E. N. Verla, and K. O. Nwarnorh, "Microplastics Toxic Chemical Interaction: A Review Study on Quantified Levels, Mechanism and Implication," Univ. Teknol. Fed. Niger., 2019.

[12] K. Pivnenko, L. G. Jakobsen, M. K. Eriksen, A. Damgaard, and T. F. Astrup, "Challenges in plastics recycling," Proc. Fifteenth Waste Manag. Landfill Symp. Sardinia 2015, 2015.

[13] J. Gasde, J. Woidasky, J. Moesslein, and C. Lang-Koetz, "Plastics recycling with tracer-basedsorting: Challenges of a potential radical technology," Sustain., vol. 13, no. 1, pp. 1-16, 2021.

[14] M. Cole, P. Lindeque, E. Fileman, C. Halsband, R. Goodhead, J. Moger, and T. S. Galloway, "Microplastic ingestion by zooplankton," Environ. Sci. Technol, vol. 47, no. 12, p. 6646-6655, 2013.

[15] M. A. Browne, P. Crump, S. J. Niven, E. Teuten, A. Tonkin, T. Galloway, and R. Thompson, "Accumulation of microplastic on shorelines woldwide: sources and sinks," Environ. Sci. Technol, vol. 45, no. 21, p. 9175-9179, 2011.

[16] M. A. Browne, P. Crump, S. J. Niven, E. Teuten, A. Tonkin, T. Galloway, and R. Thompson, "Accumulation of microplastic on shorelines woldwide: Sources and sinks," Environ. Sci. Technol., vol. 45, no. 21, pp. 9175-9179, 2011.

[17] W. F. Firmansyah, O. Setiani, and H. D. Darundiati, "Kondisi Sungai di Indonesia Ditinjau dari Daya Tampung Beban Pencemaran : Studi Literatur," J. Serambi Eng., vol. 6, no. 2, 2021.

[18] S. Lambert and M. Wagner, "Characterisation of nanoplastics during the degradation of polystyrene," Chemosphere, vol. 145, p. 265-268, 2016.

[19] D. Neves, P. Sobral, J. L. Ferreira, and T. Pereira, "Ingestion of microplastics by commercial fish off the Portuguese coast," Mar. Pollut. Bull, vol. 101, no. 1, p. 119-126, 2015.

[20] L. I. Devriese, V. D. M. D. Meulen, T. Maes, K. Bekaert, I. Paul-Pont, L. Frere, J. Robbens, and A. D. Vethaak, "Microplastic' contamination in brown shrimp (Crangon crangon, Linnaeus 1758) from coastal waters of the Southern North Sea and Channel area," Mar. Pollut. Bull, vol. 98, no. 1-2, p. 179-187, 2015.

[21] M. Pflieger, P. Makorič, K. M. Viršek, and S. Koren, "Extraction of Organochlorine Pesticides from Plastic Pellets and Plastic Type Analysis," J Vis Exp, vol. 125, p. 55531, 2017.

[22] M. Forte, G. Lachetta, M. Tussellino, R. Carotenuto, M. Prisco, M. DeFalco, V. Laforgia, and S. Valiante, "Polystyrene nanoparticles internalization in human gastric adenocarcinoma cells," Toxicol. Vitr., vol. 31, pp. 126-136, 2016.

[23] A. P. Walczak, E. Kramer, P. J. M. Hendriksen, P. Tromp, J. P. F. G. Helsper, V. D. M. Zande, I. M. C. M. Rietjens, and H. Bouwmeester, "Translocation of differently sized and charged polystyrene nanoparticles in in vitro intestinal cell models of increasing complexity," Nanotoxicology, vol. 9, no. 4, p. 453-461, 2015.

[24] I. Fiorentino, R. Gualtieri, V. Barbato, V. Mollo, S. Braun, A. Angrisani, M. Turano, M. Furia, P. A. Netti, and D. Guarnieri, "Energy independent uptake and release of polystyrene nanoparticles in primary mammalian cell cultures," Exp. Cell Res, vol. 330, no. 2, p. 240-247, 2015.

[25] G. J. Mahler, M. B. Esch, E. Tako, T. Southard, S. D. Archer, E. P. Glahn, and M. L. Shuler, "Oral exposure to polystyrene nanoparticles affects iron absorption," Nat. Nanotechnol, vol. 7, no. 4, p. 264-271, 2012.

[26] I. Inkielewicz-Stepniak, L. Tajber, G. Behan, H. Zhang, M. W. Radomski, C. Medina, and M. J. Santos-Martinez, "The Role of Mucin in the Toxicological Impact of Polystyrene Nanoparticles," Materials (Basel)., vol. 11, no. 5, p. 724, 2018.

[27] J. A. Varela, M. G. Bexiga, C. Åberg, J. C. Simpson, and K. A. Dawson, "Quantifying sizedependent interactions between fluorescently labeled polystyrene nanoparticles and mammalian cells," J. Nanobiotechnol, vol. 10, no. 1, p. 39, 2012.

[28] S. Deville, R. Penjweini, N. Smisdom, K. Notelaers, I. Nelissen, J. Hooyberghs, and M. Ameloot, "Intracellular dynamics and fate of polystyrene nanoparticles in A549 Lung epithelial cells monitored by image (cross-) correlation spectroscopy and single 15," Biochim. Biophys. Acta, Mol. Cell Res, vol. 1853, no. 10, p. 2411-2419, 2015.

[29] A. Salvati, C. Aberg, D. T. Santos, J. Varela, P. Pinto, I. Lynch, and K. A. Dawson, "Experimental and theoretical comparison of intracellular import of polymeric nanoparticles and small molecules: toward models of uptake kinetics," Nanomedicine, vol. 7, no. 6, p. 818-826, 2011. 
[30] J. McCarthy, X. Gong, D. Nahirney, M. Duszyk, and M. Radomski, "Polystyrene nanoparticles activate ion transport in human airway epithelial cells.," Int. J. Nanomedicine, vol. 6, pp. 13431356, 2011.

[31] H. W. Chiu, T. Xia, Y. H. Lee, C. W. Chen, J. C. Tsai, and Y. J. Wang, "Cationic polystyrene nanospheres induce autophagic cell death through the induction of endoplasmic reticulum stress," Nanoscale, vol. 7, no. 2, p. 736-746, 2015.

[32] P. Ruenraroengsak and T. D. Tetley, "Differential bioreactivity of neutral, cationic and anionic polystyrene nanoparticles with cells from the human alveolar compartment: robust response of alveolar type 1 epithelial cells," Part. Fibre Toxicol, vol. 12, no. 1, p. 19, 2015.

[33] V. Paget, S. Dekali, T. Kortulewski, R. Grall, C. Gamez, K. Blazy, O. Aguerre-Chariol, S. Chevillard, A. Braun, and P. Rat, "Specific uptake and genotoxicity induced by polystyrene nanobeads with distinct surface chemistry on human lung epithelial cells and macrophages," PLoS One, vol. 10, no. 4, p. No. e0123297, 2015. 